\title{
A COMPARATIVE IMMUNE RESPONSE TO PISCIRICKETTSIA SALMONIS GROWN IN ALTERNATIVE MEDIA
}

\author{
Daniel L Makrinos ${ }^{1 *}$, Grant M Dickey ${ }^{2^{*}}$, Timothy J Bowden ${ }^{1 \S}$ \\ ${ }^{1}$ School of Food and Agriculture, University of Maine, Orono, ME 04469 \\ ${ }^{2}$ School of Marine Sciences, University of Maine, Orono, ME 04469
}

\begin{abstract}
Piscirickettsia salmonis is a facultative, intracellular pathogen which is the causative agent of piscirickettsiosis in several fresh and saltwater fish species. The disease has caused significant economic losses particularly to Chilean aquaculture. Isolation and growth of the pathogen is generally carried out in cell culture, however alternative media have been published for growth in liquid and agar culture. We investigate the growth of $P$. salmonis in three defined artificial media through optical density, cell counts, and a $P$. salmonis-specific TaqMan assay. Despite previous indications that iron was essential for in vitro growth, iron restriction was achieved and induced protein variations between mediums upon 1D and 2D PAGE-gel electrophoresis analysis. Furthermore, we analyze the immune response in Atlantic salmon to $P$. salmonis using immune serum. These protein differences could indicate how intracellular pathogens grow in different in vitro systems and provide additional insight for future vaccine development.
\end{abstract}

\section{KEYWORDS}

Please provide 5 key words: Piscirickettsia salmonis, SRS, P. salmonis Growth, $P$. sal Protein, Intracellular Bacteria

*These authors have contributed equally to this work.

§Timothy Bowden. Tel.: +207-581-2772; Fax: +207-581-2729.

E-mail address: Daniel.Makrinos.maine.edu 